\title{
KELUARGA DAN PROBLEMATIKANYA MENUJU KELUARGA SAKINAH (Tinjauan dalam Persfektif Marrital Psikologi)
}

\author{
N. Kardinah \\ Fakultas Psikologi UIN Sunan Gunung Djati Bandung
}

This journal was made to describe a real condition of family's affair and all aspects within family life, how to solve family business and discussing hints and strategies to create a sakinah's family (harmonic family). Adults - in this article-were the subject and are seen as individuals that prepare themselves to step onto marriage life-which would then all fundamental aspects of marriage life and family business must be learned by adults so they can manage their family and marriage life.

An ideal family was built upon consensus of vision and basis of knowledge and not just following emotional pressure and lust. Everything has its own way, either in techniques and strategies to implement all ideal theories in real life. A family which has clear vision and orientation of how to solve all family business can make an ideal roadmap regarding family education for its member; they would also can preserve and teach a meaningful moral values, social, tradition and religious values accordingly.

Keywords: Family, marriage life, vision

\section{Pendahuluan}

Kehidupan berkeluarga merupakan salah satu tugas perkembangan yang harus dilalui seorang manusia dewasa baik laki-laki maupun wanita. Keluarga merupakan tugas perkembangan yang sangat banyak, sangat penting dan sangat sulit diatasi. Bahkan sekalipun orang dewasa telah mempunyai pengalaman kerja, telah kawin, dan telah menjadi orang tua (bapak dan ibu), mereka harus tetap melakukan penyesuaian diri dengan peran-peran dalam keluarga.

Tulisan ini mencoba mendeskripsikan kondisi ril keluarga dan berbagai problematikanya, cara mengatasinya dan menyodorkan bagaimana kiat-kiat menuju keluarga sakinah. Semua ini dimaksudkan agar orang dewasa yang menuju jenjang perkawinan mempunyai dasar-dasar yang harus dibangun sehingga tidak mengalami kesulitan penyesuaian perkawinan dan membuahkan hasil yang memuaskan.

\section{Definisi Keluarga}

Menurut Kamus Besar Bahasa Indonesia, keluarga merupakan komunitas tekecil pada masyarakat yang terdiri dari ayah, ibu dan anak. Pola Keluarga yang populer di masyarakat:

a. Keluarga Inti: ayah-ibu dan anak

b. Keluarga Besar: ayah-ibu-anak \& keluarga Dekat yang tinggal satu atap

c. Keluarga Anak Tunggal: ayah-ibu \& seorang anak

d. Keluarga tanpa anak: suami - istri

e. Keluarga dengan ibu bekerja

f. Keluarga dengan janda/duda: Ayah/ibu dan anak

g. Keluarga dengan anak angkat 
h. Keluarga dengan beda agama

i. Keluarga dengan beda suku

Tipe keluarga menurut Moch. Djawad Dahlan:

a. Tipe adu tinju (Keluarga yang penuh dengan kekerasan)

b. Tipe Kuburan (Keluarga yang tidak ada komunikasi antar anggota keluarga)

c. Tipe Pasar (Keluarga yang penuh hiruk pikuk)

d. Tipe restoran (Keluarga yang hanya membicarakan menu makanan)

e. Tipe hotel (Keluarga ada di rumah hanya untuk melepas lelah/tidur)

f. Tipe Sekolah (Suasana keluarga yang sarat dengan nuansa edukatif)

g. Tipe Masjid (Suasana keluarga yang sarat dengan nuansa keagamaan)

\section{Problematika Umum Keluarga}

Keluarga dengan komunitas yang berbeda melahirkan problematika yang berbeda pula. Beberapa problematika yang sering muncul dalam keluarga antara lain: problem ekonomi, pendidikan, status sosial, kasih sayang, problem perkawinan dan sebagainya.

Problematika perkawinan merupakan bidikan pembahasan penulis dalam makalah ini. Asumsi dasar pemilihan problematika ini karena penulis memandang faktor satu ini membawa dampak terhadap problematika lainnya, walaupun faktor lain juga sama pentingnya dalam membangun sebuah keluarga.

Problematika perkawinan yang sering muncul dalam keluarga adalah adanya kesulitan dalam perkawinan. Antara lain kesulitan penyesuaian perkawinan, penyesuaian terhadap pasangan, penyesuaian seksual, penyesuaian diri dengan keluarga pasangan, dan penyesuaian diri dengan masa orang tua.

3. Kesulitan dalam penyesuaian perkawinan

Faktor penyebab kesulitan penyesuaian perkawinan sebagai berikut:

a. Persiapan terbatas untuk perkawinan. Walaupun realitas zaman sekarang penyesuaian seksual lebih mudah dibanding masa lalu, karena banyak informasi tentang seks tersedia baik di rumah, sekolah, dan tempat lain. Akan tetapi kebanyakan pasangan suami istri hanya menerima sedikit persiapan di bidang ketrampilan domestik, mengasuh anak dan manajemen keuangan

b. Peran dalam perkawinan. Kecenderungan perubahan peran dalam perkawinan bagi pria dan wanita, dan konsep yang berbeda tentang peran ini yang dianut kelompok social dan religius yang berbeda membuat penyesuaian dalam perkawinan semakin sulit masa sekarang dibanding masa lalu ketika peran masih begitu ketat dianut.

c. Kawin muda. Perkawinan dan kedudukan sebagai orang tua sebelum orang muda menyelesaikan pendidikan mereka dan secara ekonomis independent membuat mereka tidak mempunyai kesempatan untuk memiliki pengalaman yang dipunyai oleh teman-teman yang tidak kawin atau orangorang yang telah mandiri sebelum kawin. Hal ini mengakibatkan sikap iri hati dan menjadi halangan dalam penyesuaian perkawinan 
d. Konsep yang tidak realistis tentang perkawinan. Orang dewasa yang bekerja di sekolah dan perguruan tinggi, dengan sedikit atau tanpa pengalaman bekerja, cenderung mempunyai konsep yang tidak realistis tentang makna perkawinan berkenaan dengan pekerjaan, deprivasi, pembelanjaan uang, atau perubahan dalam pola hidup yang berdampak pada perceraian.

e. Perkawinan campur. Penyesuaian terhadap kedudukan sebagai orang tua dan dengan para saudara dari pihak istri dan sebaliknya, jauh lebih sulit pada perkawinan antar agama daripada bila keduanya berasal dari latar belakang agama dan budaya yang sama.

f. Pacaran yang dipersingkat. Periode atau masa pacaran yang dipersingkat sering terjadi masa sekarang dibanding masa lalu. Kondisi seperti ini pasangan hanya mempunyai sedikit waktu untuk memecahkan banyak masalah tentang penyesuaian sebelum mereka melangsungkan perkawinan.

g. Konsep perkawinan yang romantis. Banyak orang dewasa memiliki konsep perkawinan romantis yang berkembang pada masa remaja. Harapan yang berlebihan tentang tujuan dan hasil perkawinan sering membawa kekecewaan yang menambah kesulitan penyesuaian terhadap tugas dan tanggung jawab perkawinan.

h. Kurangnya identitas. Apabila seseorang merasa bahwa keluarga, teman, dan rekannya memperlakukannya sebagai "suami Susan" atau apabila wanita merasa bahwa kelompok sosialnya menganggap dirinya hanya sebagai "ibu rumah tangga" walaupun dia seorang wanita karier yang berhasil, ia biasa saja kehilangan identitas diri sebagai individu yang sangat dijunjung dan dinilai tinggi sebelum perkawinan.

4. Kesulitan dalam Penyesuaian dengan Pasangan

Faktor-faktor yang mempengaruhi kesulitan penyesuaian terhadap pasangan:

a. Konsep pasangan ideal. Dalam memilih pasangan baik pria maupun wanita sampai sejauh tertentu dibimbing konsep pasangan ideal yang dibentuk selama masa dewasa. Semakin orang berlatih menyesuaikan diri terhadap realitas semakin sulit penyesuaian dilakukan terhadap pasangan.

b. Pemenuhan kebutuhan. Apabila penyesuai yang baik dilakukan, pasangan harus memenuhi kebutuhan yang berasal dari pengalaman awal. Apabila orang dewasa perlu pengenalan, pertimbangan, prestasi dan status sosial agar bahagia, pasangan harus membantu pasangan lainnya untuk memenuhi kebutuhan tersebut.

c. Kesamaan latar belakang. Semakin sama latar belakang suami dan istri (se-qufu), semakin mudah untuk saling menyesuaikan diri. Bagaimana pun juga apabila latar belakang mereka sama setiap orang dewasa mencari pandangan unik mengenai kehidupan. Semakin berbeda pandangan hidup makin sulit melakukan penyesuaian.

d. Minat dan kepentingan bersama. Kepentingan yang saling bersamaan mengenai suatu hal dilakukan pasangan cenderung 
membawa penyesuaian yang baik dari kepentingan bersama yang sulit dilakukan dan dibagi bersama.

e. Keserupaan nilai. Pasangan yang menyesuaikan diri dengan baik mempunyai nilai yang lebih serupa dibanding pasangan dengan penyesuaian buruk.

f. Konsep peran. Setiap lawan pasangan mempunyai konsep yang pasti mengenai bagaimana seharusnya bagaimana peranan suami dan istri, atau setiap orang mengharapkan pasangannya memainkan perannya. Jika harapan terhadap peran tidak terpenuhi akan mengakibatkan konflik dan penyesuain yang buruk.

g. Perubahan dalam pola hidup. Penyesuaian terhadap pasangan berarti mengorganisasikan pola kehidupan, merubah persahabatan dan kegiatan-kegiatan sosial, serta merubah persyaratan pekerjaan terutama bagi seorang istri. Penyesuaian-penyesuaian ini sering diikuti dengan konflik emosional.

5. Kesulitan dalam penyesuaian seksual

Beberapa faktor penting yang mempengaruhi penyesuaian seksual:

a. Perilaku terhadap seks. Sikap terhadap seks dipengaruhi oleh bagaimana cara pria dan wanita menerima informasi seks selama masa anak-anak dan remaja. Sekali perilaku yang tidak menyenangkan dikembangkan maka akan sulit sekali untuk dihilangkan.

b. Pengalaman seks masa lalu. Cara orang dewasa dan teman sebaya bereaksi terhadap masturbasi, petting dan hubungan suami istri sebelum menikah, ketika me- reka masih muda dan cara pria dan wanita merasakan itu sangat mempengaruhi perilakunya terhadap seks.

c. Dorongan seksual. Dorongan seksual berkembang lebih awal pada pria daripada wanita dan cenderung tetap demikian. Pada wanita timbul secara periodik dengan turun naik selama siklus menstruasi. Variasi ini berpengaruh terhadap kenikmatan dan penyesuain seks.

d. Pengalaman seks marital awal. Kepercayaan bahwa hubungan seksual menimbulkan ekstasi yang tidak sejajar dengan pengalaman lain, menyebabkan banyak dewasa muda merasa begitu pahit dan susah sehingga penyesuaian seksual akhir sulit atau tidak mungkin dilakukan.

e. Sikap terhadap penggunaan alat kontrasepsi. Akan terjadi sedikit konflik dan ketegangan jika suami istri setuju menggunakan alat kontrasepsi dibanding pasangan yang berbeda tentang sarana tersebut.

f. Efek Vasektomi. Apabila seseorang menjalani operasi vasektomi, maka akan hilang ketakutan akan kehamilan yang tidak diinginkan. Akan tetapi bagi pria akan mempertanyakan kepriaannya.

6. Kesulitan dalam penyesuaian dengan keluarga pasangan

Faktor yang mempengaruhi penyesuaian diri dengan pihak keluarga pasangan antara lain:

a. Stereotif tradisional. Stereotif yang secara luas mengenai "ibu mertua yang refresentatif" dapat menimbulkan perangkat mental yang tidak menyenangkan mengenai 
orang usia lanjut (mereka bossy dan campur tangan) dapat menambah masalah bagi keluarga pasangan.

b. Keinginan untuk mandiri. Orang yang menikah muda cenderung menolak berbagai saran dan petunjuk dari orang tua mereka, walaupun mereka menerima bantuan keuangan, dan khususnya mereka menolak campur tangan keluarga pasangan.

c. Keluargaisme. Penyesuaian dalam perkawinan akan lebih pelik apabila salah satu pasangan tersebut apabila salah satu pasangan tersebut menggunakan waktunya untuk keluarganya daripada mereka sendiri ingin berikan. Bila pasangan terpengaruh oleh keluarga, apabila ada anggota keluarga berkunjung dalam waktu lama atau hidup bersama selamanya.

d. Mobilitas sosial. Orang dewasa muda yang status sosialnya meningkat di atas anggota keluarga atau di atas status keluarga pasangannya akan tetap membawa mereka dalam latar belakngnya. Akan tetapi banyak yang menimbulkan konflik keluarga.

e. Anggota keluarga berusia lanjut. Merawat anggota keluarga berusia lanjut merupakan faktor yang sangat pelik dalam penyesuaian perkawinan. Sikap tidak menyenangkan terhadap orang tua dan keyakinan bahwa orang muda harus bebas dari urusan keluarga apalagi kalau memiliki anak.

f. Bantuan keuangan untuk keluarga pasangan. Bila pasangan muda harus membantu atau memikul tanggung jawab bantuan keuangan bagi pihak keluarga pasangan, hal ini sering membawa hubungan keluarga yang tidak beres. Dapat menimbulkan kemarahan dan menyinggung keluarga pasangan lainnya.

7. Kesulitan dalam penyesuaian diri dengan Masa Tua

Beberapa faktor yang mempengaruhi penyesuaian diri dengan masa orang tua:

a. Sikap terhadap kehamilan. Sikap wanita terhadap masa orang tua diwarnai oleh kondisi fisik dan emosionalnya selama mengandung. Sikap menyenangkan atau sebaliknya akan nampak setelah melahirkan.

b. Sikap terhadap masa orang tua. Orang dewasa akan mnyesuaikan diri lebih baik dengan masa orang tua jika ia menginginkan anak karena ia merasa bahwa bayi itu merupakan unsur esensial terhadap perkawinan yang bahagia. Bukan karena unsur keluarga atau tekanan sosial.

c. Usia orang tua. Orang tua muda cenderung kurang bertanggung jawab terhadap masa orang tua dan tidak menginginkan campur tangan orang lain mengenai kesenangan hidupnya. Sedang pada orang lebih dewasa cenderung bertanggung jawab dan memperhatikan keluarga.

d. Jenis kelamin anak. Sikap orang dewasa terhadap masa orang tua jauh menyenangkan jika mereka mempunyai anak dengan jenis kelamin yang mereka kehendaki.

e. Jumlah anak. Apabila seorang dewasa mempunyai jumlah anak yang ideal berpengaruh terhadap penyesuaian masa tua lebih baik.

f. Harapan orang tua. Orang tua yang memiliki konsep anak yang diimpikan akan 
menyesuaikan diri dengan seberapa baik anak itu diukur menurut yang ideal.

g. Perasaan keseimbangan tugas orang tua. Konflik tentang metode pelatihan anak bisa membingungkan dan menimbulkan rasa cemas dalam melakukan kerja dengan baik. Konflik ini juga mempengaruhi penyesuaian diri dengan masa orang tua.

h. Sikap terhadap perubahan peran. Masa orang tua berarti bahwa baik pria maupun wanita harus belajar untuk memainkan peran yang lebih berorientasi pada keluarga daripada berorientasi kepada pasangan. Bagaimana pria dan wanita bereaksi terhadap perubahan peran ini akan mempunyai pengaruh terhadap penyesuaian mereka dengan masa orangtua.

i. Watak anak. Anak-anak yang mudah untuk diatur dan yang responsif dan penuh kasih sayang, membuat orang tua merasa dihargai bagi waktu dan usahanya telah dikorbankan bagi anak-anak. Hal ini merupakan efek yang menyenangkan orang tua sehingga memudahkan mereka tentang sikap orangtua peranan mereka sebagai orang tua.

\section{Kriteria Keberhasilan Perkawinan}

Keberhasilan perkawinan tercermin pada besar kecilnya hubungan interpersonal dan pola perilaku. Sampai sejauh tertentu kriteria ini bervariasi bagi orang yang berbeda dan bagi perkawinan pada usia yang berbeda. Unsur-unsur ini dapat digunakan untuk menilai tingkat penyesuaian perkawinan seseorang. Kriteria tersebut antara lain: a. Kebahagiaan suami istri. Suami istri yang bahagia memperoleh kebahagiaan bersama akan membuahkan kepuasan yang diperoleh dari peran yang mereka lakukan bersama. Memiliki cinta yang matang dan mantap satu sama lainnya, dapat melakukan penyesuaian seksual dengan baik serta dapat menerima peran sebagai orang tua.

b. Hubungan yang baik antara anak dan orang tua. Hubungan yang baik antara anak dengan orang tua mencerminkan keberhasilan penyesuaian perkawinan.

c. Penyesuaian yang baik dari anak-anak. Penyesuan diri yang baik dari anak dengan teman-temannya, maka ia akan disenangi teman sebayanya, berhasil dalam belajar dan bahagia di sekolah. Itu merupakan tolak ukur keberhasilan peran sebagai orang tua

d. Kemampuan untuk memperoleh kepuasan dari perbedaan pendapat. Perbedaan pendapat yang terjadi di antara anggota keluarga yang tidak dapat dielakkan dapat menimbulkan salah satu dari tiga hal berikut, adanya ketegangan tanpa pemecahan, salah satu mengalah demi perdamaian, atau masing-masing anggota keluarga mencoba untuk saling mengerti pandangan dan pendapat orang lain

e. Kebersamaan. Menikmati waktu untuk berkumpul bersama merupakan bukti keberhasilan penyesuaian perkawinan. Hubungan keluarga yang baik pada awal-awal tahun perkawinan menentukan keberhasilan selanjutnya. 
f. Penyesuaian yang baik masalah keuangan. Sumber utama perselisihan dan kejengkelan dalam keluarga adalah masalah keuangan. Besar kecilnya pendapatan ditentukan oleh kemampuan keluarga membelanjakan hasil pendapatan tersebut. Bagaimana cara agar ia tidak terlilit uang dan dapat menikmati hasil usahanya, bila perlu istri dapat membantu pendapatan bukan mengeluhkan pendapatan suami.

g. Penyesuaian yang baik dari keluarga pasangan. Apabila suami istri memiliki hubungan yang baik dengan keluarga pasangan, khususnya mertua, ipar, kecil kemungkinan untuk terjadinya konflik dan ketegangan hubungan dengan mereka.

\section{Upaya Menuju Keluarga Sakinah}

Setiap pasangan hidup manusia pastilah mendambakan keluarga yang bahagia lahir dan batin, tenang, tentram, saling menghormati dan menghargai, saling mengasihi, penuh cinta dan kasih sayang, seolah taman indah yang mempesona, itulah syurga. Baiti jannati. Bila ada syurga di dunia ini itulah keluarga yang bahagia. Sebaliknya bila ada neraka di dunia ini, itulah keluarga yang berantakan

Keluarga adalah basic, tempat seseorang memulai hidup. Penanaman nilai, moral dan agama dimulai dari keluarga. Keluarga yang harmonis akan melahirkan anak-anak yang harmonis, demikian sebaliknya.

Sebuah keluarga harus mempunyai visi, pandangan yang dibangun atas dasar ilmu pengetahuan, bukan sekadar emosi dan perasaan. Semua itu ada ilmunya, dan ada prak-tiknya.
Perbedaan antara impian yang dibayangkan dan kenyataan yang dihadapi sering menjadi pangkal konflik sebuah keluarga. Suami kecewa terhadap istri ternyata ia tidak seperti yang diinginkannya, istri kecewa terhadap suami ternyata ia bukan tipe laki-laki yang diharapkannya. Ironisnya mereka sudah saling mengenal lama, mengapa baru mengatakan tidak cocok setelah menikah?

Semua itu berasal dari sesuatu yang sederhana, namun menentukkan masa depan keluarga, yaitu tidak mengetahui tujuan menikah. Barangkali ketika ia melangsungkan akad pernikahan, yang ada di kepalanya agar dapat berkumpul dengan pasangannya secara sah, atau karena desakan pasangan, atau karena iri karena teman-temannya sudah berkeluarga, atau paksaan orang tua dan lain sebagainya. Semua itu menjadi alasan yang menguatkan ketidakcocokkan antarpasangan. Padahal masalah intinya mereka tidak memiliki tujuan atau visi dari menikah.

Dengan visi yang jelas keluarga mampu menanamkan nilai-nilai agama, sosial, dan budaya kepada anak-anaknya secara proporsional. Dalam kaitan ini Marwah Daud Ibrahim dalam bukunya Teknologi, Emansipasi, dan Transendensi yang dikutip Saikhul Hadi memberikan beberapa alternatif peran strategis yang dapat dilakukan keluarga.

Pertama, Keluarga sebagai pendidik dan model hidup. Orang tua menjadi pendidik inti dari ana-anaknya. Metoda yang paling tepat dalam pendidikan keluarga adalah melalui contoh dan kebiasaan yang dilakukan secara 
konsisten diikuti anak-anaknya. Contoh dalam melakukan ibadah salat dan puasa.

Kedua, Keluarga sebagai motivator, ibadah yang baik tidak terbatas pada konsistennya ritualitas ibadah saja tapi memasuk pada taraf fungsionaltas yang multidimensi, meliputi seluruh cipta, karsa, dan rasa manusia. Untuk itu orang tua perlu memotivasi anak-anak untuk belajar tentang alam sekitarnya. Selain untuk menambah ilmu pengetahuan, yang lebih pentinga adalah menyadari kebesaran Allah SWT.

Ketiga, Keluarga sebagai fasilitator, Keluarga diharapkan dapat memfasilitasi perkembangan anak-anaknya. Menjadi fasilitator berarti mengarahkan tanpa memaksa apalagi menentukan keinginan anaknya. Mereka tetap membutuhkan untuk memilih.

Keempat, Keluarga sebagai selektor, orang tua harus iku membantu menyaring informasi yang diserap anak-anak; baik secara langsung maupun tidak langsung. Penyaringan langsung dapat berupa pemilihan sekolah yang tepat, organisasi yang baik, buku bacaan yang sesuai, program televisi yang mendidik, dan sebagainya. Penyaringan tidak langsung dapat berdialog secara intens tentang mana yang patut dan tidak patut.

Dalam kaitan ini Abdullah Gymnastiar memberikan berbagai kiat-kiat menuju keluarga sakinah. Keluarga sakinah akan termanifestasi dalam kehidupan keluarga manakala ia telah: Mempersiapkan diri, gemar beramal, ikhlas, besih hati dan komitmen membangun sinergi dalam keluarga.
Pertama, Mempersiapkan diri: berumah tangga bukanlah hal yang mudah memerlukan persiapan untuk menitinya, baik dalam perencanaan maupun ketika mengarunginya, ia akan menjadi bagian dari sebuah penderitaan yang seolah tiada bertepi bagi siapapun yang menjalaninya.

Sejak awal Allah Swt. Telah mengingatkan kepada orang-orang yang beriman agar hati-hati dalam hal tersebut sebagaimana firman-Nya (QS At Taghabun:14): "Hai orangorang yang beriman, sesungguhnya di antara istri-istrimu dan anak-anakmu ada yang menjadi musuh bagimu, maka berhati-hatilah kamu terhadap mereka; dan jika kamu memaafkan dan tidak memarahi serta tidak mengampuni (mereka) maka sesungguhnya Allah maha pengampun lagi penyayang“.

Ayat di atas menjelaskan bisa jadi istri yang kita nikahi atau anak kita menjadi musuh, suami jadi koruptor karena desakan istri, atau kita dipermalukan karena perilaku anak-anak kita. Untuk itu pertama hal yang kita lakukan adalah bersiap diri berdoa di tengah kelemahan kita agar Allah mengaruniai kita istri dan anak yang soleh. Sebagaimana tertera dalam AlQuran (QS Al-Furqan : 74): ”...Wahai Tuhan kami karuniakanlah kepada kami istri-istri dan keturunan kami sebagai penyenang hati (Qurrata a'yun) dan jadikanlah kami imam bagi orang-orang yang bertakwa."

Selain peringatan Allah kita juga harus mempersiapkan diri dengan membekali ilmu, sebagaimana sabda Rasulullah Saw.: "Barang siapa yang menginginkan dunia (mendapatkannya) harus memakai ilmu. Barang siapa 
yang menginginkan akhirat (mendapatkannya) harus memakai ilmu. Barang siapa menginginkan dunia akhirat harus dengan ilmunya."

Hadits di atas menjelaskan dalam berkeluarga pun ada ilmunya. Ilmu berkeluarga dapat diperoleh melalui membaca, mengikuti training, kursus, mendatangi majlis-majlis taklim dan lain sebagainya. Gagalnya seorang ibu atau ayah dalam menyelesaikan masalah keluarga diakibatkan karena lemahnya keterampilan dan sikap kita dalam menyikapi dan mensiasati masalah tersebut.

Kedua, Gemar beramal; Setiap ilmu tidak akan membawa manfaat, kecuali bila sudah terwujud dalam bentuk amal. Artinya, seseorang tidak akan mendapatkan sesuatu yang ia inginkan tetapi dari apa yang ia lakukan.Oleh karena itu syarat kedua dalam berkeluarga ideal setelah menguasai ilmu adalah gemar mengamalkannya. Jangan menuntut sesuatu kepada orang lain, tetapi tuntutlah diri sendiri untuk senantiasa berbuat kebaikan semaksimal mungkin. Bukankah Allah telah berfirman (QS al-Zalzalah: 7-8): "Barang siapa berbuat kebajikan sebesar zarrah pun, niscaya ia kan melihat balasannya. Dan barang siapa berbuat kejahatan sebesar zarrah pun, niscaya ia akan melihat balasannya pula." Seorang suami yang bekerja keras menyayangi istrinya dengan ikhlas istri pun akan menyayangi suami dengan ikhlas begitupun sebaliknya.

Ketiga, Ikhlas: Sehebat apa pun amalan kita tidak akan bermanfaat di hadapan Allah, kecuali amal-amal yang dilakukan dengan ikhlas. Orang yang ikhlas adalah orang yang berbuat sesuatu tanpa berharap mendapatkan apa pun kecuali ingin dicintai Allah. Inilah bekal ketiga dalam berumah tangga.

Dalam mengarungi kehidupan berkeluarga akan banyak berhadapan dengan beragam masalah. Kita pasti akan menemukan kesulitan, kesempitan, dan kesengsaraan lahir batin, kecuali kalau kita mendapat pertolongan-Nya. Allah mengetahui persis kebutuhan kita, lebih tahu dari diri kita sendiri. Dia tahu persis masalah yang akan menimpa kita, jauh lebih tahu dari diri kita sendiri. Makanya Allah berkalam (QS. At-Thalaaq: 2): “... Barang siapa yang bertakwa kepada Allah, niscaya Dia akan mengadakan baginya jalan keluar."

Rumah tangga yang senantiasa meningkatkan ketaatannya kepada Allah akan senantiasa dikaruniai oleh-Nya jalan keluar atas segala urusan dan masalah yang dihadapinya. Rumah seluas apapun akan terasa sempit kalau penghuninya tidak ikhlas, kekayaan yang melimpah ruah tidak akan bisa dinikmati kalau tidak ikhlas. Jadi apa pun yang kita lakukan harus ikhlas seperti ikhlasnya BAB kita di pagi hari.

Keempat, Bersih hati: Setiap saat ujian dan masalah bukan tidak mungkin datang melanda rumah tangga. Bagaimana suami atau istri menyikapinya? Ternyata kunci menyikapinya adalah terletak pada Qalbu (hati). Mau dibuat rumit atau sederhana masalah itu terserah diri suami atau istri yang akan memetik hasilnya dan merasakannya.

Setiap masalah dapat menjadi rumit atau sederhana. Semuanya tergantung pada kondisi hati yang kita miliki, yang akhirnya membuat 
kita harus memutuskan harus bagaimana menyikapinya. Padahal kuncinya adalah: "Sesungguhnya tidak ada masalah dengan masalah, karena yang menjadi masalah adalah cara kita yang salah dalam menyikapi masalah.”

Oleh karena itu, hati yang bersih adalah bekal utama keempat yang harus dimiliki oleh sebuah rumah tangga, setelah mempunyai bekal ilmu, amal, dan keikhlasan. Bersih hati, tidak bisa tidak, akan menjadi senjata pamungkas dalam menyiasati serumit dan sesulit apa pun masalah yang muncul dalam keluarga. Adapun buahnya sudah dapat dipastikan adalah rumah tangga yang tenang, tentram, penuh cinta kasih, dan selalu saling mengingatkan dalam hal meningkatkan kedekatan diri kepada Allah Swt.

Kelima, Komitmen membangun sinergi dalam keluarga: Sebuah keluarga dimulai dengan adanya ijab dan qabul, begitu pun dalam kehidupan berkeluarga antara suami, istri dan anak-anak harus memahami posisi masingmasing, serta hak dan kewajibannya. Tak ubahnya seperti bangunan dengan komposisi dan bahan bangunannya. Begitu pun dengan mertua jika tidak pandai menjaga diri dapat mengaduk-aduk rumah tangga anaknya sendiri.

Suami sebagai pemimpin keluarga, tentu akan menjadi pemimpin jika ada yang dipimpin. Pemimpin yang baik adalah pemimpin yang mau bekerjasama memajukan seluruh anggota yang dipimpinnya untuk meraih kesuksesan dunia dan akhirat.

Disamping sebagai pemimpin, suami berperan sebagai pelindung, pencari rizki, pendidik keluarga, penggali potensi anggota keluarga, pengatur strategi dan komunikasi, juga peran-peran lainnya. Yang semua peran itu memerlukan persiapan fisik dan psikis agar dapat mencapai apa yang menjadi impian keluarganya.

Peran istri dapat menjadikan rumah bagaikan syurga bagi anggota keluarganya, tempat curahan hati suami dan anak-anaknya, siap melahirkan, menyusui dan membesarkan serta mendidik anak-anaknya. Serta peran-peran lainnya yang melekat pada istri, semua itu membutuhkan ilmunya agar selaras dengan apa yang dicita-citakan keluarganya yaitu "Baiti Jannati”.

Baiti jannati diidentifikasi sebagai rumah yang dapat memberikan ketenangan jiwa, menjadi pusat ilmu, pusat nasehat dan pusat berbagai kemuliaan. Pusat ketenangan rumah dan anggotanya mampu memberikan ketenangan dari berlumurnya keringat suami, bersimbah keluh, bekerja dengan keras, ia selalu merindukan untuk pulang ke rumah. Karena baginya rumah adalah sumber ketenangan dan ketentraman yang tidak akan diperoleh dalam hiruk pikuknya kehidupan dunia.

Rumah sebagai pusat ilmu; mencirikan adanya motivasi dalam mencari ilmu. Kegigihan sebuah rumah tangga dalam meluaskan ilmu adalah kekayaan yang amat berharga.

Rumah sebagai pusat nasehat: rumah tangga yang bahagia adalah rumah tangga yang dengan sadar menjadikan kebiasaan saling menasehati, serta saling mengoreksi kebenaran dan kesabaran, sebagai bagian kekayaannya. 
Adapun rumah sebagai pusat kemuliaan: jadikan rumah tangga kita bagaikan sinar matahari yang menerangi kegelapan, menumbuhkan bibit-bibit dan menyegarkan yang layu, yang selalu dinanti dan membuat gembira yang terkena tebaran cahayanya. Pancarkan cahaya kebahagiaan itu khususnya kepada orang tua kita dan kepada orang-orang di sekitar kita.

\section{Penutup}

Demikianlah deskripsi umum keluarga dan problematikanya menuju keluarga sakinah. Tentunya belum mencakup berbagai aspek mengenai keluarga hal ini membuka peluang penulisan penulis selanjutnya. Akan tetapi secara umum kita dapat mengambil hikmah dari apa yang penulis tulis mengenai keluarga ini. Bahwa keluarga adalah komunitas terkecil yang terdiri dari ayah, ibu, dan anak. Walaupun dalam realitas kehidupan ada berbagai keluarga seperti yang penulis jelaskan di atas.

Kehidupan keluarga tidaklah mudah akan tetapi akan banyak problematika yang menghadang baik itu mulai dari masalah anak, ekonomi, pendidikan, kasih sayang, penyesuaian pasangan perkawinan dan masalah lainnya. Semua itu membutuhkan pemecahan yang logis, efektif dan efesien agar apa yang menjadi impian keluarga dapat terwujud, yaitu keluarga yang bahagia.

Keluarga bahagia (keluarga sakinah), memerlukan persiapan ilmu, mampu mengamalkannya, dilakukan dengan ikhlas, selalu menjaga hati dan membutuhkan komitmen untuk bersinergi dalam peran masing-masing. Serta mampu menjadikan rumah sebagai baiti jannati yang mampu memberikan ketenangan dan ketentraman bagi semua anggota keluarganya, menjadikan rumah sebagai pusat ilmu, pusat nasehat, dan pusat berbagai kemuliaan.

\section{Daftar Pustaka}

Gymnastiar, Abdullah. (2005). Sakinah (Manajemen Qalbu untuk Keluarga), Bandung: Khas MQ

Departemen Agama. (2000) Al-Quran dan Terjemahannya, Bandung,: Diponegoro,

Depdiknas, (1989) Kamus Besar Bahasa Indonesia, Jakarta: Balai Pustaka

Hurlock, Elizabeth B. (1993). Psikologi Perkembangan (Suatu Pendekatan Sepanjang Rentang Kehidupan), Jakarta: Erlangga

Hadi, Saikhul. (2004). Kiat Membangun Keluarga Bahagia, Jogjakarta: Cinta Pena 
Psympathic, 2009, Vol. I, No.1: 109 - 120 